\title{
Copolymers of PBT and Nylon 4T
}

\author{
R. J. GAYMANS, J. L. DE hAAN, and O. VAN NIEUWENHUIZE*
}

University of Twente, Polymer Technology Laboratory, Department of Chemical Technology, P.O. Box 217, 7500 AE Enschede, The Netherlands

\begin{abstract}
SYNOPSIS
Polybutylene terephthalate-nylon 4T copolymers (PBT-PA 4T) are synthesized from the diamide of diaminobutane and dimethyl terephthalate (DMT) with butane diol and more DMT in a concentration range of up to $50 \%$ PA $4 \mathrm{~T}$. The polymerization conditions were similar to those for PBT: first, a melt polymerization, followed by solid-state post-condensation. The materials were studied by differential scanning analysis (DSC) (melting and crystallization behavior) and dynamic mechanical thermal analysis (DMTA) (glass transitions and torsion moduli). The water absorptions were determined at $100 \% \mathrm{RH}$. By increasing the PA 4T content in the copolymers, melting temperatures increased strongly, heats of fusion decreased slightly, and glass transition temperatures increased linearly. The torsion moduli above the glass transition temperature were higher. (C) 1993 John Wiley \& Sons, Inc.
\end{abstract}

Keywords: PBT copolymer • polyesteramide • diaminobutane • nylon 4T copolymer

\section{INTRODUCTION}

Polybutylene terephthalate (PBT) is a very interesting engineering plastic. The polymer has a high structural regularity and, due to this, a high crystallinity and crystallization rate. Results of this are moduli above the glass transition temperature high and good solvent resistance. PBT is processable and has a low water absorption. A disadvantage of this polyester is its relatively low melting $\left(220^{\circ} \mathrm{C}\right)$ and glass transition temperatures $\left(45^{\circ} \mathrm{C}\right)$.

Modification by copolymerization, e.g., with amides, usually causes a lowering of the melting temperature and order. An exception is the regular alternating polyesteramides ( PEA). These alternating PEA show thermal and mechanical behavior and have a unit cell structure typical of semicrystalline homopolymers. ${ }^{1-4}$ The most-studied alternating PEA is synthesized from 1,6-hexanediamine and 1,6-hexanediol with terephthalic acid (T6T6). ${ }^{2-6} \mathrm{~T} 6 \mathrm{~T} 6$ possesses physical properties comparable to those of polyethylene terephthalate; it has a $T_{m}$ of $25^{\circ} \mathrm{C}$, a $T_{g}$

* To whom all correspondence should be addressed. Present address: Euro Patents Office, Rijswijk, The Netherlands.

Journal of Polymer Science: Part A: Polymer Chemistry, Vol, 31, 575-580 (1993) (C) 1993 John Wiley \& Sons, Inc. of $49^{\circ} \mathrm{C}$ ( $66 \% \mathrm{RH}$ ), but the $G$ modulus above $T_{g}$ drops sharply. ${ }^{5}$ Williams synthesized its alternating PEA according to the following scheme ${ }^{2}$ :

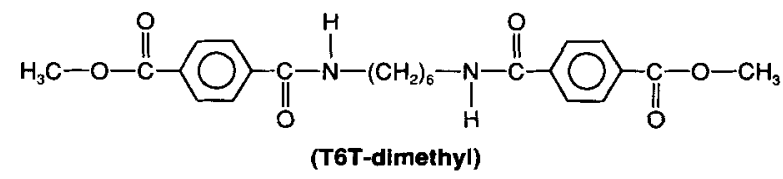

+ excess hexanediol + catalyst $\rightarrow$ ester interchange $260^{\circ} \mathrm{C} \rightarrow$

polycondensation $275^{\circ} \mathrm{C}, 0.1 \mathrm{~mm} \mathrm{Hg} \rightarrow \mathrm{CH}_{3} \mathrm{OH}$<smiles>CNC(=O)c1ccc(C(=O)I)cc1</smiles>

The T6T-dimethyl was made with the half acid chloride ester of dimethylterephthalate (DMT) and a diamine. ${ }^{8}$ Manzini ${ }^{6}$ made the T6T-dimethyl with excess DMT, the diamine, and $\mathrm{Li}\left(\mathrm{OCH}_{3}\right)$ as a catalyst. Of the alternating PEA with short chain glycols $\left(\mathrm{C}_{2}-\mathrm{C}_{5}\right)$ and short chain diamine (e.g., $\left.\mathrm{C}_{4}\right)$ only polymers of very low molecular weight could be obtained. (This is probably due to competing side reactions. ${ }^{2}$ ) 
Randomization of PEA decreases the order of these systems and as a result, a lowering of the mechanical properties (e.g., moduli above their $T_{g} .{ }^{1-3}$ In this article we report on the synthesis and properties of PEA synthesized from 1,4-butanediamine and 1,4-butanediol with DMT, which is a family of PBT copolymers.

\section{EXPERIMENTAL}

\section{Materials}

Dimethylterephthalate (DMT), 1,4-butanediamine (BDA), and 1,4-butanediol (BDO) were obtained from Merck. BDA and BDO were distilled prior to use.

The catalyst was a solution of $1.48 \mathrm{~g}$ tetraisopropyltitanate and $0.1 \mathrm{~g} \mathrm{Na}$ in $30 \mathrm{~mL}$ of distilled $n$ butanol.

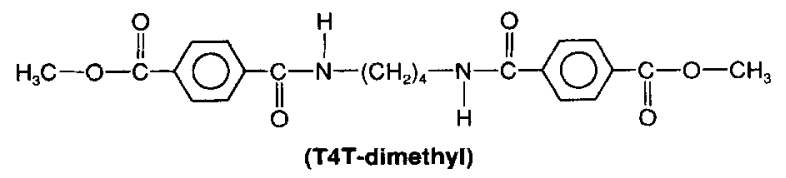

$N, N^{\prime}$ - bis ( $p$ - carbomethoxybenzoyl) butanedi amine (T4T-dimethyl) $)^{6,9}$ was synthesized through the following procedure: $111 \mathrm{~g}(0.6 \mathrm{~mol}) \mathrm{DMT}, 5 \mathrm{~g}$ (0.06 mol) BDA, $395 \mathrm{~mL}$ anhydrous toluene, 106 $\mathrm{mL}$ of anhydrous methanol, and $10 \mathrm{~mL} \mathrm{Li}\left(\mathrm{OCH}_{3}\right)$ (1.89 $\mathrm{M}$ in methanol) were mixed in a flask with a stirrer, condenser, and nitrogen inlet. The flask was heated to reflux for $40 \mathrm{~h}$. During this time the reaction product precipitated. The precipitate was separated by hot filtration, washed twice with hot toluene and once with hot methanol, and was subsequently dried $\left(24 \mathrm{~h}\right.$ at $\left.100^{\circ} \mathrm{C}\right)$.

\section{Polymer Synthesis}

The PEAs studied have amide concentrations of 0 $50 \mathrm{~mol} \%$ and are denoted PEA 0-50.

\section{Prepolymerization}

The reactions were carried out in a $250 \mathrm{~mL}$ glass vessel with a nitrogen inlet and mechanical stirrer. A typical example of a synthesis of a $25 \mathrm{~mol} \%$ amide sample (PEA-25) is given below; $10.0 \mathrm{~g}$ T4T-dimethyl ( $24.3 \mathrm{mmol}$ ), $9.46 \mathrm{~g} \mathrm{DMT}$ ( $48.7 \mathrm{mmol}$ ), 13.1 g BDO $(145.5 \mathrm{mmol})$, and $0.4 \mathrm{~mL}$ catalyst solution was reacted for $30 \mathrm{~min}$ at $180^{\circ} \mathrm{C}$. After this the temperature was raised to $250^{\circ} \mathrm{C}$ and vacuum applied $(10-15 \mathrm{~mm} \mathrm{Hg}$ ) for $30 \mathrm{~min}$. Subsequently the tem- perature was further increased to $265^{\circ} \mathrm{C}$ and the pressure reduced to $0.1-0.01 \mathrm{~mm} \mathrm{Hg}$ and the reaction was kept at those conditions for $1 \mathrm{~h}$.

\section{Postcondensation}

The prepolymer materials were grounded and postcondensed in the solid state, $24 \mathrm{~h}$ at $200-230^{\circ} \mathrm{C}$ in a stream of nitrogen.

\section{Characterization}

The $\eta_{\text {inh }}$ of the PEA-0-35 was measured at $25^{\circ} \mathrm{C}$ using a $0.25 \%$ solution in $\mathrm{PhOH} / \mathrm{C}_{2} \mathrm{Cl}_{4} \mathrm{H}_{2}(50 / 50$ mol \%). For PEA-40 and -50 a $0.5 \%$ solution in $96 \% \mathrm{H}_{2} \mathrm{SO}_{4}$ was used with a constant solution time of $6 \mathrm{~h}$.

\section{Thermal Analysis}

Differential scanning calorimetry (DSC) (PerkinElmer DSC-4) was used with a heating and cooling rate of $20^{\circ} \mathrm{C} / \mathrm{min}$. The melt-pressed samples were first heated to $20^{\circ} \mathrm{C}$ above their melting temperatures $\left(T_{m 1}, \Delta H_{m 1}\right)$, cooled $\left(T_{c}\right)$, and heated again $\left(T_{m 2}, \Delta H_{m 2}\right)$. The area under the melting curve was used as the heat of fusion, the peak maximum as the melting temperature.

\section{Water Absorption at $100 \%$ RH}

A melt-pressed sample was first dried in a vacuum oven $\left(24 \mathrm{~h}\right.$ at $\left.100^{\circ} \mathrm{C}\right)$ and weighed. After the water absorption the sample was weighed again. Two methods were used: (method 1 ) the sample was suspended in boiling water for $24 \mathrm{~h}$, and (method 2) the sample was kept in a desiccator above water at $20^{\circ} \mathrm{C}$ for 1 month.

\section{Dynamic Mechanical Analysis}

With a Myrenne (ATM 3) torsion pendulum instrument the torsion moduli $G^{\prime}$ and $G^{\prime \prime}$ were analyzed at a constant frequency of $1 \mathrm{~Hz}$ and a heating rate of $1^{\circ} \mathrm{C} / \mathrm{min}$.

\section{RESULTS AND DISCUSSION}

\section{Synthesis}

The PBT copolymers with BDA were prepared with the "T4T-dimethyl." The T4T-dimethyl was synthesized from BDA and a large excess of DMT in a methanol/toluene mixture at reflux temperature. ${ }^{6}$ 


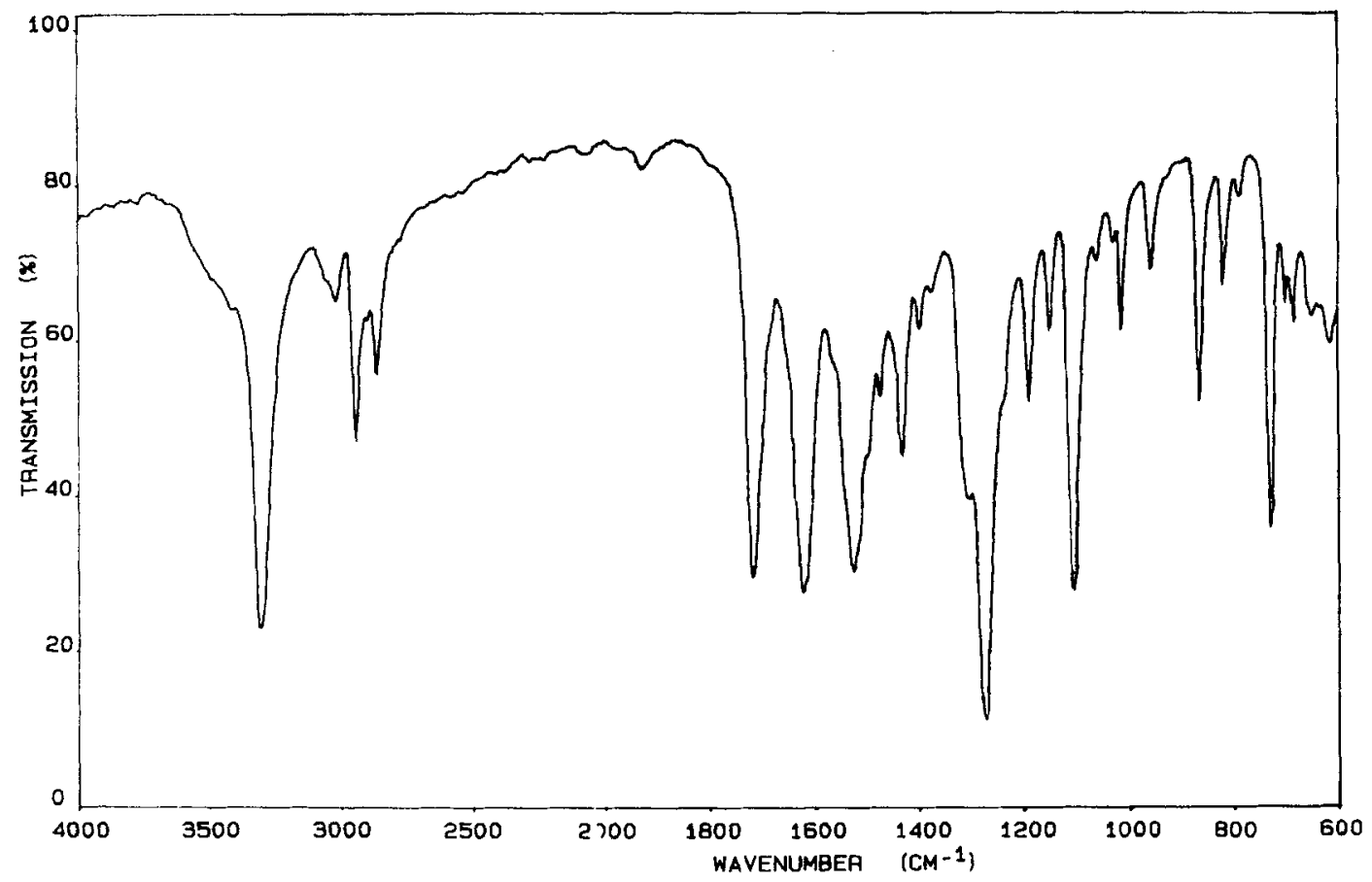

Figure 1. IR diagram of T4T-dimethyl.

Soon a suspension was formed of the monoamide which was slowly converted to the T4T-dimethyl. As a catalyst $\mathrm{LiOCH}_{3}$ was added (and this also avoids salt formation). With IR spectroscopy, the formation of amide groups could be observed and in the T4T-dimethyl the amide carbonyl band (1640 $\left.\mathrm{cm}^{-1}\right)$ was as strong as the ester carbonyl band ( 1720 $\mathrm{cm}^{-1}$ ) (Fig. 1). The T4T-dimethyl has a melting point of $257^{\circ} \mathrm{C}$ and a heat of fusion of $144 \mathrm{~J} / \mathrm{g}$.

\section{Prepolymer}

The first stage of the reaction is a transesterification step during which the methyl esters of DMT and the T4T-dimethyl are replaced by butyl esters of BDO. After this step the temperature is raised and vacuum is applied.

This polycondensation step is carried out in two stages: first at $250^{\circ} \mathrm{C}$ and a moderate vacuum ( 20 mbar) and then at $265^{\circ} \mathrm{C}$ and high vacuum conditions $(0.1 \mathrm{mbar})$. The influence of the transesterification conditions were studied on PEA-25. In order to prevent cyclization of butanediol the transesterification reactions were carried out at $200^{\circ} \mathrm{C}$ or lower temperatures. The lower limit is formed by the ability of DMT and BDO to keep the reaction mixture liquid. The results of these reactions are given in Table I. The effect of reaction temperature (170-

Table I. Prepolymerization Conditions: PEA-25 (25\% Amide)

\begin{tabular}{|c|c|c|c|c|}
\hline \multirow[b]{2}{*}{ No. } & \multicolumn{2}{|c|}{ Transesterfication } & \multicolumn{2}{|c|}{$\begin{array}{l}\text { Polycondensation } \\
\left(1 \mathrm{~h} \text { at } 265^{\circ} \mathrm{C}\right)\end{array}$} \\
\hline & $\begin{array}{c}T \\
\left({ }^{\circ} \mathrm{C}\right)\end{array}$ & $\begin{array}{c}t \\
(\min )\end{array}$ & $\begin{array}{c}P \\
(\mathrm{mmHg})\end{array}$ & $\begin{array}{c}\eta_{\text {inh }} \\
(d L / g)\end{array}$ \\
\hline 1 & 200 & 45 & $0.1-0.01$ & 0.69 \\
\hline 2 & 180 & 45 & $0.03-0.01$ & 0.83 \\
\hline 3 & 180 & 30 & $0.05-0.01$ & 0.94 \\
\hline 4 & 180 & 30 & $0.05-0.01$ & 0.74 \\
\hline 5 & 180 & 20 & $0.02-0.01$ & 0.85 \\
\hline 6 & 180 & 20 & $0.02-0.01$ & 0.78 \\
\hline 7 & 170 & 30 & $0.03-0.01$ & 0.78 \\
\hline
\end{tabular}


Table II. Postcondensation Reactions: PEA-25 (25\% Amide), 24 h Nitrogen Atmosphere

\begin{tabular}{lcc}
\hline & $\begin{array}{c}\text { Reaction Temperature } \\
\left({ }^{\circ} \mathrm{C}\right)\end{array}$ & $\begin{array}{c}\eta_{\text {inh }} \\
(\mathrm{dL} / \mathrm{g})\end{array}$ \\
\hline No. & - & 0.83 \\
1A & 220 & 1.29 \\
1B & 230 & 1.03 \\
2 & - & 0.85 \\
2A & 200 & 1.23 \\
2B & 210 & 1.13 \\
$2 \mathrm{C}$ & 220 & 1.30 \\
3 & - & 0.94 \\
$3 \mathrm{~A}$ & 230 & 1.19 \\
$3 \mathrm{~B}$ & 240 & 1.13 \\
\hline
\end{tabular}

$200^{\circ} \mathrm{C}$ ) and time ( $\left.20-45 \mathrm{~min}\right)$ is small, but it seems that with a transesterification temperature of 170 $180^{\circ} \mathrm{C}$ somewhat higher viscosities of the prepolymer were obtained.

\section{Postcondensation}

High molecular weight polyesters are usually obtained by postcondensation in the solid state at 10 $20^{\circ} \mathrm{C}$ below the melting temperature. ${ }^{10}$ The results of some postcondensation reactions of PEA-25 are given in Table II. The best results were obtained by a solid-state postcondensation of PEA-25 in the region $200-220^{\circ} \mathrm{C}$.

\section{Amide Content Variation}

PEAs were synthesized with varying amounts of amide. If the amount of the high melting T4T-dimethyl is increased, it will become more difficult to

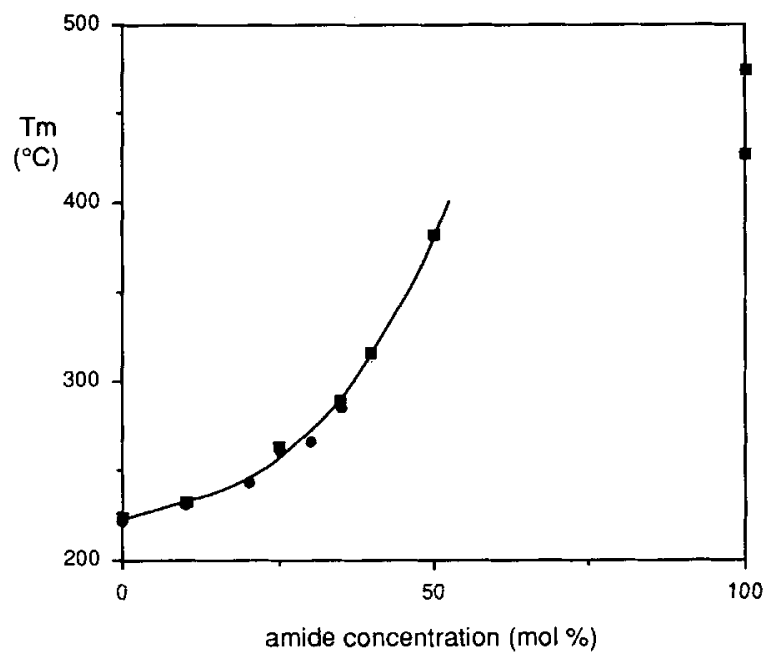

Figure 2. Melting temperatures: (ש) first and (๑) second run.

keep the reaction mixture liquid during the transesterification step. These reactions (PEA-35-50) are carried out at $190^{\circ} \mathrm{C}$ with a larger excess of BDO.

The results of the reactions with different copolymers compositions are listed in Table III. The viscosities of the PEA decreased with increasing amide content. The reason for this is as yet unknown.

\section{DSC}

The melt-pressed polymers were scanned to $20^{\circ} \mathrm{C}$ above their melting points, cooled at $20^{\circ} \mathrm{C} / \mathrm{min}$, and scanned again at $20^{\circ} \mathrm{C} / \mathrm{min}$. The observed melting transitions and heats of fusion are given in Table III and Figures 2 and 3.

There were hardly any differences between $T_{m 1}$ and $T_{m 2}$ of the melt-pressed samples. The melting

Table III. Properties of PEAs

\begin{tabular}{|c|c|c|c|c|c|c|c|c|c|}
\hline No. & $\begin{array}{c}\text { PEA } \\
\text { (Amide \%) }\end{array}$ & $\begin{array}{c}\eta_{\text {inh }} \\
(\mathrm{dL} / \mathrm{g})\end{array}$ & $\begin{array}{l}T_{m, 1} \\
\left({ }^{\circ} \mathrm{C}\right)\end{array}$ & $\begin{array}{c}T_{c} \\
\left({ }^{\circ} \mathrm{C}\right)\end{array}$ & $\begin{array}{l}T_{m, 2} \\
\left({ }^{\circ} \mathrm{C}\right)\end{array}$ & $\begin{array}{l}\Delta H_{m, 1} \\
(\mathrm{~J} / \mathrm{g})\end{array}$ & $\begin{array}{l}\Delta H_{m, 2} \\
(\mathrm{~J} / \mathrm{g})\end{array}$ & $\begin{array}{l}T_{g, \mathrm{dry}} \\
\left({ }^{\circ} \mathrm{C}\right)\end{array}$ & $\begin{array}{l}T_{g, w e t} \\
\left({ }^{\circ} \mathrm{C}\right)\end{array}$ \\
\hline ind. $^{a}$ & 0 & 1.01 & 224 & 177 & 224 & 52 & 50 & 50 & - \\
\hline 8 & 0 & 1.66 & 223 & 190 & 222 & 44 & 43 & 47 & 40 \\
\hline 9 & 10 & 1.32 & 232 & 201 & 232 & 47 & 53 & 59 & 40 \\
\hline 10 & 20 & - & - & 216 & 244 & - & 44 & - & - \\
\hline 11 & 25 & 1.19 & 264 & 236 & 261 & 42 & 41 & 78 & 48 \\
\hline 12 & 30 & 0.51 & - & 227 & 268 & - & 47 & 85 & - \\
\hline 13 & 35 & 0.31 & 289 & 255 & 286 & 39 & 27 & 88 & 48 \\
\hline 14 & 40 & ${ }^{\mathbf{b}}$ & 316 & - & - & 23 & - & 116 & 44 \\
\hline 15 & 50 & 0.43 & 382 & - & - & 42 & - & 110 & - \\
\hline $4, T^{c}$ & 100 & 0.19 & $428 / 475$ & - & - & 108 & - & - & - \\
\hline
\end{tabular}

arnite KN 159904.

b Did not dissolve completely.

- Reference 11, cast film. 


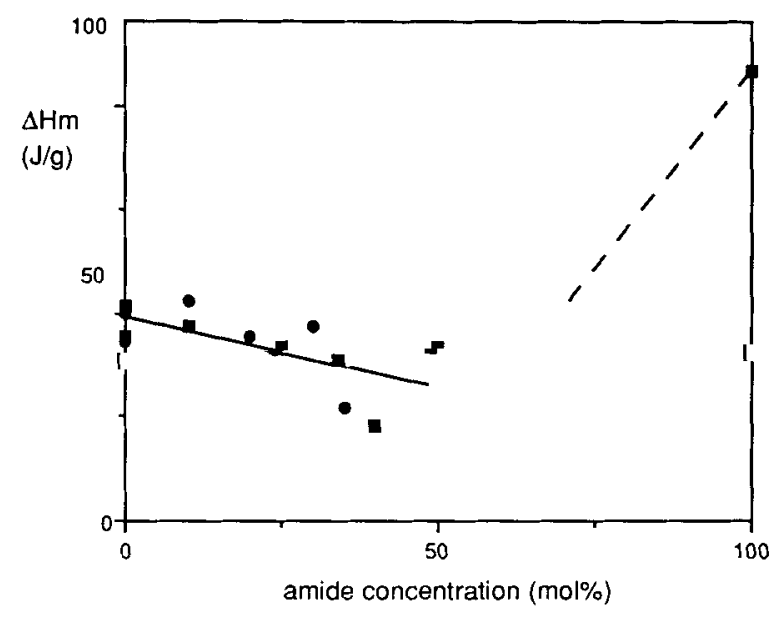

Figure 3. Heats of fusion: ( $\boldsymbol{a})$ first and ( $\bullet$ ) second run.

temperatures increase with amide content without showing the usual melting point depression of copolymers. The difference between the crystallization temperature $\left(\mathrm{T}_{c}\right)$ and the second melting temperature $\left(\mathrm{T}_{m, 2}\right)$ remains almost constant.
There was a considerable spread of values of the heats of fusion $\left(\Delta H_{m}\right)$, but the overall trend is that there is only a slight decrease with increasing amide content compared with the PBT homopolymer. This means that we are dealing with copolymers which are nearly as highly ordered as PBT and which crystallize as fast as PBT.

\section{Mechanical Properties}

The torsion properties were studied on melt-pressed strips, dried, and conditioned at $100 \% \mathrm{RH}$. The glass transition $\left(G_{\max }^{\prime \prime}\right)$ was in all cases a single transition (Fig. 4) and the glass transition temperatures increased linearly with the amide content ( Fig. 5, Table III). This effect was much stronger for the dry samples than for the wet samples. The copolymers kept their $G^{\prime}$ above their $T_{g}$ remarkably well (Fig. 4) up to a factor of 2 better than the PBT and sustained high moduli to appreciably higher temperatures. The high torsion moduli above $T_{g}$ also suggest that these PEA copolymers have a high degree of order.

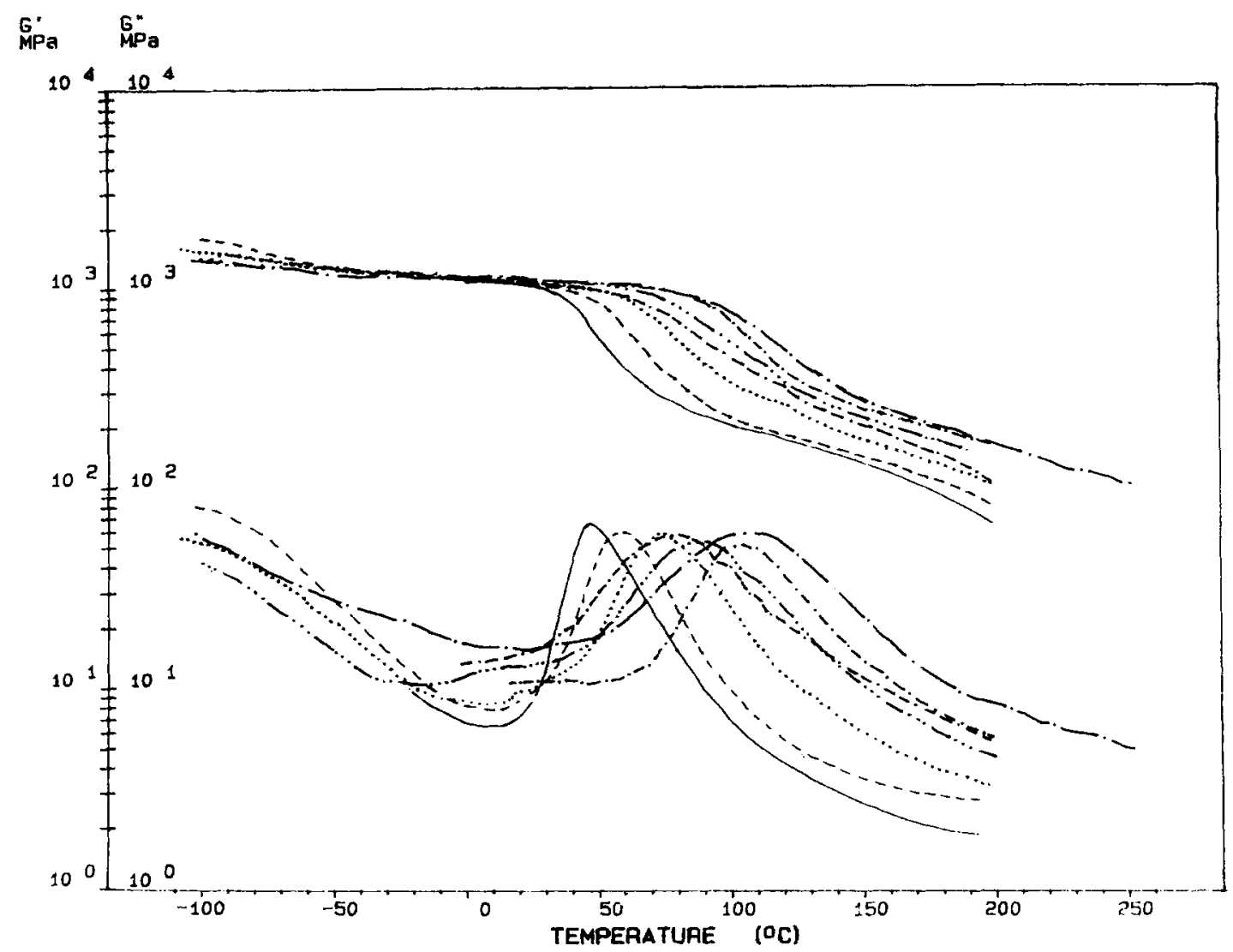

Figure 4. Dynamic mechanical analysis, $G^{\prime}$ and $G^{\prime \prime}:(-)$ PBT, (- - ) PEA-10, (.....) PEA-25, (_ _ - ) PEA-30, (......) PEA-35, (-..-) PEA-40, (- - - ) PEA-50. 


\section{Water Absorption}

The water absorption at $100 \% \mathrm{RH}$ of the copolymers increases ascentotial with increasing amide content (Fig. 6). The water absorption of the boiled up samples is slightly higher than for samples conditioned at RT. Up to PEA-25 the water absorption increase is small.

\section{Solubility}

PEA proved to be insoluble in almost every solvent. In the PBT solvent $\mathrm{PhOH} / \mathrm{C}_{2} \mathrm{Cl}_{4} \mathrm{H}_{2}$ PEA-0-35 only dissolved at higher temperatures and PEA-40-50 not at all. PEA is soluble in $\mathrm{H}_{2} \mathrm{SO}_{4}$ but this solvent degrades the polymers.

\section{CONCLUSIONS}

PBT has a high order but not so high melting $\left(220^{\circ} \mathrm{C}\right)$ and glass transition temperatures $\left(45^{\circ} \mathrm{C}\right)$. Nylon 4, T has a high order similar to PBT with, however, a very high melting temperature (425/ $475^{\circ} \mathrm{C}$ ), which is too high for melt processing. ${ }^{11} \mathrm{Co}$ polymers of PBT and nylon 4, T were synthesized by first making a T4T-dimethyl. Starting with this T4T-dimethyl the synthesis of the copolyesteramides is similar to that of PBT. The molecular weights of the copolymers were found to decrease with amide concentration.

As expected, the $T_{b}$, as well as the $T_{m}$ and the torsion moduli, increased with amide concentration, at higher temperatures. The order and the rate of crystallization in these copolymers remained high. The water absorption increased but stayed reason-

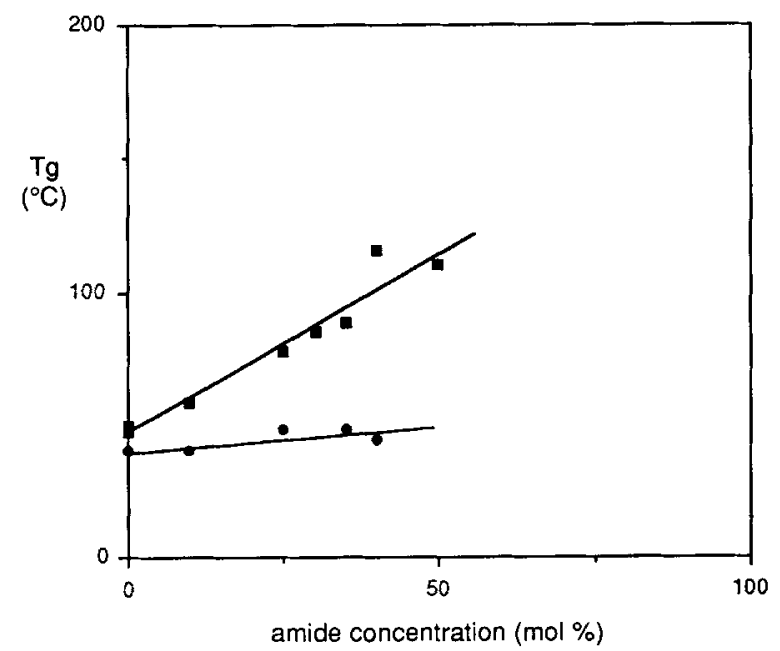

Figure 5. Glass transition temperatures: dry (ש) and at $100 \% \mathrm{RH}(\bullet)$.

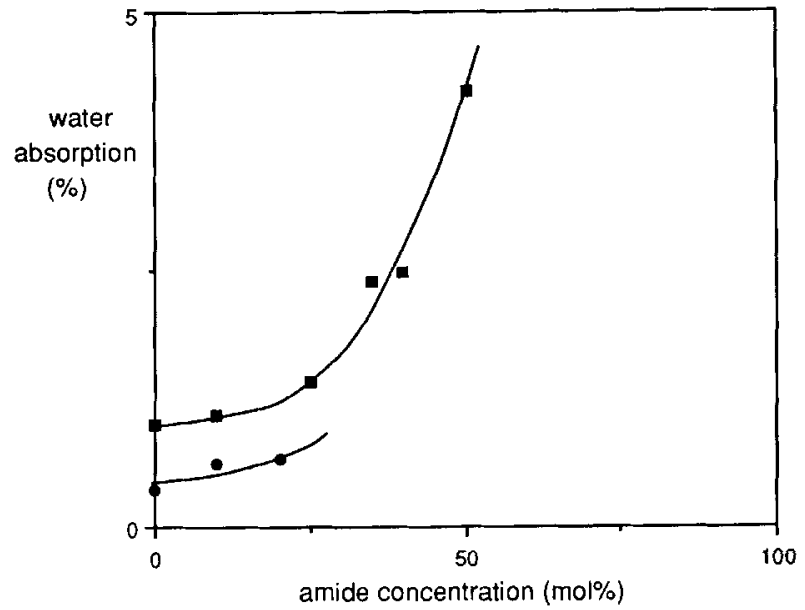

Figure 6. Water absorption at $100 \% \mathrm{RH}$. Conditions: (a) $24 \mathrm{~h}$ at $100^{\circ} \mathrm{C},(-) 1$ month at $20^{\circ} \mathrm{C}$.

ably low up to PEA-25 and the solvent resistance improved.

Thus, it is possible to modify PBT with $1,4-\mathrm{bu}$ tanediamine to copolymers with not only higher glass transition temperatures but also higher melting temperatures and better mechanical properties.

This work is part of the research program of the University of Twente and was financially supported by DSM Research, The Netherlands. The authors wish to thank Dr. E. Roerdink (DSM) for his active interest in the project.

\section{REFERENCES AND NOTES}

1. L. Castaldo, F. De Candia, G. Maglio, R. Palumbo, and G. Strazza, J. Appl. Polym. Sci., 27, 1809 (1982).

2. J. L. R. Williams, T. M. Laakso, and L. E. Contois, J. Polym. Sci., 61, 353 (1962).

3. M. Cesari, G. Perego, and A. Melis, Eur. Polym. J., 12, 585 (1976).

4. G. Conte and L. D'Ilario, Polymer, 20, 559 (1979).

5. C. Borri, E. Sorta, and L. Zotteri, Polymer, 16, 565 (1975).

6. G. Manzini, V. Creszenzi, A. Ciana, G. Della Fortuna, and L. Zotteri, Eur. Polym. J., 9, 941 (1973).

7. I. Goodman and D. A. Starmer, Eur. Polym. J., 27, 515 (1991).

8. J. L. R. Williams, T. M. Laakso, K. R. Dunham, D. G. Borden, J. VanDenBerghe, J. A. VanAllen, and D. D. Reynolds, J. Org. Chem., 25, 817 (1960).

9. GB Pat. 1365952, SNAM Progetti, S.p.a, Milan, 1971.

10. L. H. Buxbaum, J. Appl. Polym. Sci. Appl. Polym. Symp., 35, 59 (1979).

11. R. J. Gaymans, J. Polym. Sci. Polym. Chem. Ed., 23, 1599 (1985).

Received February 5, 1992

Accepted June 5, 1992 